\title{
Atomistic Mechanisms of The Tautomerization of The G.C Base Pairs Through The Proton Transfer: Quantum-Chemical Survey
}

\section{Ol'ha Brovarets' ( $D$ o.o.brovarets@gmail.com )}

Institute of Molecular Biology and Genetics National Academy of Sciences of Ukraine: Institut molekularnoi biologii i genetiki Nacional'na akademia nauk Ukraini https://orcid.org/0000-0002-8929293X

\section{Alona Muradova}

Taras Shevchenko National University of Kyiv: Kiivs'kij nacional'nij universitet imeni Tarasa Sevcenka

\section{Dmytro Hovorun}

Institute of Molecular Biology and Genetics National Academy of Sciences of Ukraine: Institut molekularnoi biologii i genetiki Nacional'na akademia nauk Ukraini

\section{Research Article}

Keywords: G.C base pair, Proton transfer, Tautomer, H-bond, Quantum-chemical calculations

Posted Date: September 16th, 2021

DOI: https://doi.org/10.21203/rs.3.rs-867324/v1

License: (c) (1) This work is licensed under a Creative Commons Attribution 4.0 International License. Read Full License

Version of Record: A version of this preprint was published at Journal of Molecular Modeling on December 1st, 2021. See the published version at https://doi.org/10.1007/s00894-021-04988-7. 


\section{Abstract}

This study is devoted to the investigation of the $\mathrm{G} \cdot \mathrm{C}^{\star \mathrm{t}}{ }_{\mathrm{O} 2}(\mathrm{WC}) \leftrightarrow \mathrm{G}^{\star} \mathrm{NH}_{3} \cdot \mathrm{C}^{\star \mathrm{t}}(\mathrm{WC}), \mathrm{G} \cdot \mathrm{C}^{\star} \mathrm{O}_{2}(\mathrm{WC}) \leftrightarrow \mathrm{G}^{\star} \mathrm{NH}_{3} \cdot \mathrm{C}^{\star}$ $(\mathrm{WC})$ and $\mathrm{G}^{*} \cdot \mathrm{C}^{*} \mathrm{O} 2_{2}(\mathrm{WC}) \leftrightarrow \mathrm{G}^{*}{ }_{\mathrm{NH} 3} \cdot \mathrm{C}\left(\mathrm{W}_{\mathrm{WC}}\right)$, tautomerization reactions occurring through the proton transfer, obtained at the MP2/6-311++G(2df,pd)//B3LYP/6-311++G(d,p) level of theory in gas phase under normal conditions $(T=298.15 \mathrm{~K})$. These reactions lead to the formation of the $\mathrm{G}^{*}{ }_{\mathrm{NH}} \cdot \mathrm{C}^{* t}(\mathrm{WC}), \mathrm{G}^{*} \mathrm{NH}_{3} \cdot \mathrm{C}^{*}(\mathrm{WC})$ and $\mathrm{G}^{*}{ }_{\mathrm{NH} 3} \cdot \mathrm{C}\left(\mathrm{w}_{\mathrm{WC}}\right)_{\downarrow}$ base pairs by the participation of the $\mathrm{G}^{*} \mathrm{NH}_{3}$ base with $\mathrm{NH}_{3}$ group. Gibbs free energies of activation for these reactions are $6.43,11.00$ and $1.63 \mathrm{kcal} \cdot \mathrm{mol}^{-1}$, respectively. All of these tautomerization reactions are dipole active. Finally, we believe that these non-dissociative processes, which are tightly connected with the tautomeric transformations of the G.C base pairs, play outstanding role in the supporting of the spatial structure of the DNA and RNA molecules with various functional purposes.

\section{Introduction}

In recent years according to the analysis of the literature [1-6], the interest of researchers to the investigation of the prototropic tautomerism significantly increased. It is obviously connected with the fact that this research topic is multidisciplinary and covers wide areas of knowledge such as chemistry, in particular biochemistry, biology, including structural and quantum, molecular and quantum pharmacology, condensed matter physics, crystal physics, electronic technologies, biomolecular technologies etc. [7-12].

It occurs intensive accumulation of the data within the framework of the classical models, describing these processes [13-17], and also it occurs successful searches of both novel atomistic mechanisms of the prototropic tautomerization of the molecular objects [18-21], as well as novel instruments of the penetration into the course of these processes.

Shortly saying, now the mechanisms of the tautomerization of the base pairs, which are accompanied by the significant changing of the geometry of the tautomerizing base pair [22-24], actively enter the arena. It is suggested that exactly these tautomeric transitions are not only responsible for the structural transitions in the nucleic acids, as well as for the supporting of the unique spatial structures of the latest, which are responsible for the certain biological functions.

Aim of this work is to deepen the existing ideas about the quantum mechanisms of the tautomerization of the $\mathrm{G} \cdot \mathrm{C}$ pairs of nucleotide bases through the proton transfer along the intermolecular neighboring $\mathrm{H}$ bonds as their intrinsic property. We have chosen for its successful realization biologically important $\mathrm{G} \cdot \mathrm{C}$ base pairs, which monomers are in the basic and rare tautomeric forms.

As a result of the provided quantum-chemical investigations for the first time it was revealed the following regularities. 
Tautomerizations of the G.C base pairs are controlled by the transition states, joined by the intermolecular $\mathrm{H}$-bonds and covalent bridges.

In all cases without any exception mechanisms of the tautomerization are step-by-step realized by the proton transfer.

\section{Computational Methods}

Density functional theory calculations of the geometry and vibrational frequencies. Equilibrium geometries of the investigated G.C base pairs and transition states (TSs) of their tautomerizations, as well as their harmonic vibrational frequencies have been calculated, using Gaussian'09 program package [25] at the B3LYP/6-311 ++G(d,p) level of theory [26-30], which approved itself successfully for the calculations of the similar systems and processes and shown acceptable level of accuracy and adequacy of the obtained results [30,31]. A scaling factor that is equal to 0.9668 has been applied in the present work for the correction of the harmonic frequencies for all complexes [20, 21, 32].

We have confirmed local minima and transition states, localized by Synchronous Transit-guided QuasiNewton method [33], on the potential energy landscape by the absence or presence, respectively, of one imaginary frequency in the vibrational spectra of the complexes.

All reaction pathways have been reliably confirmed by providing intrinsic reaction coordinate (IRC) calculations [33] from each TS in the forward and reverse directions at the B3LYP/6-311 ++G(d,p) level of theory.

All calculations have been performed in the continuum with $\varepsilon=1$, that adequately reflects the processes occurring in real biological systems without deprivation of the structurally-functional properties of the bases in the composition of the DNA or RNA molecules and satisfactorily models the substantially hydrophobic recognition pocket of the DNA-polymerase machinery as a part of the replisome [34, 35].

Single point energy calculations. We continued geometry optimizations with electronic energy calculations as the single point calculations at the MP2/6-311 ++G(2df,pd) level of theory [36, 37].

The Gibbs free energy G for all structures was obtained in the following way:

$\mathrm{G}=\mathrm{E}_{\mathrm{el}}+\mathrm{E}_{\mathrm{corr}}(1)$

where $E_{e l}$ - electronic energy and $E_{c o r r}-$ thermal correction.

QTAIM analysis. Bader's quantum theory of Atoms in Molecules (QTAIM) [38] was applied to analyse the electron density distribution, using program package AIMAll [39].

The presence of the bond critical point (BCP), namely the so-called $(3,-1) \mathrm{BCP}$, and a bond path between the donor and acceptor of the $\mathrm{H}$-bond, as well as the positive value of the Laplacian at this $\operatorname{BCP}(\Delta \rho>0)$, 
were considered as criteria for the formation of the $\mathrm{H}$-bond [40-43]. Wave functions were obtained at the B3LYP/6-311 + + G(d,p) level of theory, used for geometry optimisation.

The atomic numbering scheme for the bases is conventional and rare tautomeric forms of the $\mathrm{G}$ and $\mathrm{C}$ bases are marked by an asterisk $(*)[4]$.

\section{Obtained results and their discussion.}

In this work investigated tautomerization pathways of the G.C base pairs are presented on Fig. 1 and their discussion is outlined below.

It is interesting to note that $\mathrm{G} \cdot \mathrm{C}^{\star \mathrm{t}}{ }_{\mathrm{O} 2}(\mathrm{WC})$ base pair (Fig. 1) tautomerizes through the double proton transfer along the $\mathrm{N} 1 \mathrm{H} . . . \mathrm{N} 3$ and $\mathrm{O} 2 \mathrm{H} . . . \mathrm{N} 2 \mathrm{H}$-bonds and via the $\mathrm{TS}_{\mathrm{G} \cdot \mathrm{C}^{*} \mathrm{tO}}(\mathrm{WC}) \leftrightarrow \mathrm{G}^{*} \mathrm{NH} 3 \cdot \mathrm{C}^{*}(\mathrm{WC})$, which are stabilized by the participation of the two intermolecular (C)N4H...06(G) and (C)O2H...N2(G) H-bonds and (G) N1-H-N3(C) covalent bridge. Eventually, this reaction leads to the formation of the $\mathrm{G}^{*}{ }_{\mathrm{NH}} \cdot{ }^{\cdot{ }^{* t}}(\mathrm{WC})$ base pair, stabilized by three intermolecular $\mathrm{N} 4 \mathrm{H} . . .06, \mathrm{~N} 3 \mathrm{H} . . . \mathrm{N} 1$ and $\mathrm{N} 2 \mathrm{H} . . . \mathrm{O} 2 \mathrm{H}$-bonds. Exactly the proton transfer along the lower $\mathrm{O} 2 \mathrm{H} . . . \mathrm{N} 2 \mathrm{H}$-bond leads to the formation of the $\mathrm{NH}_{3}$ group at the $\mathrm{G}$ base.

Formed $\mathrm{G}^{*} \mathrm{NH}_{3} \cdot \mathrm{C}^{* t}(\mathrm{WC})$ base pair can transform via the mutual rotation of the bases around the middle $\mathrm{N} 3 \mathrm{H}$...N1 $\mathrm{H}$-bond, leading to the new reverse $\mathrm{G}^{*} \mathrm{NH}_{3} \cdot \mathrm{C}^{\star \mathrm{t}}(\mathrm{rWC})$ base pair, stabilized by the $\mathrm{N} 3 \mathrm{H} . . .06, \mathrm{~N} 4 \mathrm{H} \ldots$ $\mathrm{N} 1$ and $\mathrm{N} 2 \mathrm{H} . . . \mathrm{N} 4 \mathrm{H}$-bonds. Transition state of this interconversion $\mathrm{TS}_{\mathrm{G}^{*} \mathrm{NH} 3 \cdot \mathrm{C}^{\star} \mathrm{t}(\mathrm{WC}) \leftrightarrow \mathrm{G}^{\star} \mathrm{NH} 3 \cdot \mathrm{C}^{\star} \mathrm{t}(\mathrm{rWC})}$ is joined by three $\mathrm{N} 4 \mathrm{H} . . . \mathrm{N} 1, \mathrm{~N} 3 \mathrm{H} . . . \mathrm{N} 1, \mathrm{~N} 2 \mathrm{H} . . . \mathrm{N} 4 \mathrm{H}$-bonds and single $\mathrm{N} 2 . . . \mathrm{N} 3$ van der Waals contact.

Another reaction $-\mathrm{G} \cdot \mathrm{C}^{\star}{ }_{\mathrm{O} 2}(\mathrm{WC}) \leftrightarrow \mathrm{G}^{*} \mathrm{NH}_{3} \cdot \mathrm{C}^{\star}(\mathrm{WC})$ - occurs via the transfer of the proton, localized at the $\mathrm{N} 1$ nitrogen atom of the $\mathrm{G}$ base, to the $\mathrm{N} 3$ nitrogen atom of the $\mathrm{C}^{*}{ }_{02}$ base and of the proton, localized at the $\mathrm{O} 2$ oxygen atom of the $\mathrm{C}^{\star}{ }_{02}$ base to the $\mathrm{N} 2$ atom of the $\mathrm{NH}_{2}$ amino group of the $\mathrm{G}$ base and finally leads to the $\mathrm{G}^{*} \mathrm{NH}_{3} \cdot \mathrm{C} *(\mathrm{WC})$ base pair by the participation of the $\mathrm{G}^{*}{ }_{\mathrm{NH} 3}$ base with $\mathrm{NH}_{3}$ group. Transition state $\mathrm{TS}_{\mathrm{G} \cdot \mathrm{C}^{*} \mathrm{O} 2(\mathrm{WC}) \leftrightarrow \mathrm{G}^{*} \mathrm{NH} 3 \cdot \mathrm{C}^{*}(\mathrm{WC})}$ of this reaction is characterized by the $(\mathrm{G}) \mathrm{O6} \ldots \mathrm{N} 4(\mathrm{C})$ van der Waals contact and two $(\mathrm{G}) \mathrm{N} 1-\mathrm{H}-\mathrm{N} 3(\mathrm{C})$ and $(\mathrm{G}) \mathrm{N} 2-\mathrm{H}-\mathrm{O} 2(\mathrm{C})$ covalent bridges.

Formed $\mathrm{G}^{*} \mathrm{NH}_{3} \cdot \mathrm{C} *(\mathrm{WC})$ base pair can transform by the mutual rotations of the bases around the middle $\mathrm{N} 3 \mathrm{H} . . . \mathrm{N} 1 \mathrm{H}$-bond into the reverse $\mathrm{G} \cdot \mathrm{C}\left(\mathrm{rw}_{\mathrm{WC}}\right)$ base pair: $\mathrm{G}^{\star}{ }_{\mathrm{NH}} \cdot \mathrm{C}^{\star}(\mathrm{WC}) \leftrightarrow \mathrm{G} \cdot \mathrm{C}\left(\mathrm{rW}_{\mathrm{WC}}\right)$. Transition state $\mathrm{TS}_{\mathrm{G}^{\star} \mathrm{N} 3 \cdot C \star(\mathrm{WC}) \leftrightarrow G \cdot C(\mathrm{rwW})}$ of this reaction is joined by three intermolecular $\mathrm{N} 3 \mathrm{H} . . . \mathrm{N} 1, \mathrm{~N} 2 \mathrm{H} \ldots \mathrm{N} 4, \mathrm{~N} 2 \mathrm{H} . . . \mathrm{O} 2 \mathrm{H}-$ bonds and N2...N3 van der Waals contact.

The most interesting case represents the last transformation $-G^{*} \cdot C^{*}{ }_{02}(W C) \leftrightarrow G^{*}{ }_{N H 3} \cdot C\left(W_{W C}\right)_{\downarrow}$, since proton transfer within the $\mathrm{G}^{\star} \cdot \mathrm{C}^{\star}{ }_{\mathrm{O} 2}(\mathrm{WC})$ base pair leads not only to the changing of its tautomeric status, but also to its geometrical rearrangement. This reaction occurs through the proton transfer along the upper $\mathrm{O} 6 \mathrm{H} \ldots \mathrm{N} 4$ and lower $\mathrm{O} 2 \mathrm{H} . . . \mathrm{N} 2 \mathrm{H}$-bonds from the $\mathrm{O} 2$ atom of the $\mathrm{G}^{*}$ base to the $\mathrm{N} 4$ atom of the $\mathrm{C}^{\star}{ }_{02}$ base and from the $\mathrm{O} 2$ atom of the $\mathrm{C}^{*}{ }_{\mathrm{O} 2}$ base to the $\mathrm{N} 2$ atom of the $\mathrm{G}^{*}$ base, respectively. Finally, $\mathrm{C}$ base 
shifts down accordingly the $\mathrm{G}^{*}{ }_{\mathrm{NH} 3}$ base, forming the $\mathrm{G}^{*}{ }_{\mathrm{NH}} \cdot \mathrm{C}\left(\mathrm{W}_{\mathrm{WC}}\right)_{\downarrow}$ base pair by the participation of the $\mathrm{G}$ base with $\mathrm{NH}_{3}$ group.

Altogether it was revealed four $\mathrm{G} \cdot \mathrm{C}$ base pairs, involving $\mathrm{G}^{*}{ }_{\mathrm{NH} 3}$ base with $\mathrm{NH}_{3}$ group $-\mathrm{G}^{*}{ }_{\mathrm{NH}} \cdot{ }^{*} \cdot{ }^{\star t}(\mathrm{WC})$, $\mathrm{G}^{*}{ }_{\mathrm{NH} 3} \cdot \mathrm{C}^{\star \mathrm{t}}(\mathrm{rWC}), \mathrm{G}^{*}{ }_{\mathrm{NH} 3} \cdot \mathrm{C}^{\star}(\mathrm{WC})$ and $\mathrm{G}^{*}{ }_{\mathrm{NH} 3} \cdot \mathrm{C}\left(\mathrm{W}_{\mathrm{WC}}\right)$ ( Fig. 1).

In general, considered here $\mathrm{G} \cdot \mathrm{C}$ base pairs form the following order in terms of their relative Gibbs free $\Delta \mathrm{G}$ and electronic $\Delta E$ energies (in $\left.\mathrm{kcal} \cdot \mathrm{mol}^{-1}\right)$ : $\mathrm{G} \cdot \mathrm{C}\left(\mathrm{rw}_{\mathrm{WC}}\right)(0.00$ and 0.00$)<\mathrm{G}^{*}{ }_{\mathrm{NH} 3} \cdot \mathrm{C}\left(\mathrm{W}_{\mathrm{WC}}\right)_{\downarrow}(16.08$ and 14.54$)$ $<G \cdot C * t{ }_{02}(W C)\left(19.43\right.$ and 17.53) $<G * \cdot C *{ }_{02}(W C)\left(19.44\right.$ and 17.56) $<G^{*}{ }_{N H 3} \cdot C^{* t}(W C)(24.60$ and 22.32) < $\mathrm{G}^{*}{ }_{\mathrm{NH} 3} \cdot \mathrm{C} *(\mathrm{WC})(31.67$ and 30.17$)<\mathrm{G}^{*}{ }_{\mathrm{NH} 3} \cdot \mathrm{C}^{* \mathrm{t}}(\mathrm{rWC})(32.97$ and 31.80$)$.

Notably, that difference in Gibbs free and electronic energies between the classical $G \cdot C(W C)$ and reverse $\mathrm{G} \cdot \mathrm{C}\left(\mathrm{rW}_{\mathrm{WC}}\right)$ base pairs consists 11.53 and $13.09 \mathrm{kcal} \cdot \mathrm{mol}^{-1}$, respectively, while the $\mathrm{G} \cdot \mathrm{C}^{\star \mathrm{t}}{ }_{02}(\mathrm{WC})$ and $\mathrm{G} \cdot \mathrm{C}^{\star}{ }_{02}(\mathrm{WC})$ base pairs are iso-energetical (19.43 and $19.44 \mathrm{kcal} \cdot \mathrm{mol}^{-1}$, respectively).

\section{Conclusions}

This paper reports for the first time novel tautomerization mechanisms for the $\mathrm{G} \cdot \mathrm{C}$ base pairs, leading to the base pairs by the participation of the $\mathrm{G}^{*}{ }_{\mathrm{NH} 3}$ base with $\mathrm{NH}_{3}$ group: $\mathrm{G} \cdot \mathrm{C}^{\star \mathrm{t}}{ }_{\mathrm{O} 2}(\mathrm{WC}) \leftrightarrow \mathrm{G}^{\star}{ }_{\mathrm{NH}} \cdot \mathrm{C}^{* t}(\mathrm{WC})$, $\mathrm{G} \cdot \mathrm{C}^{\star}{ }_{\mathrm{O} 2}(\mathrm{WC}) \leftrightarrow \mathrm{G}^{\star} \mathrm{NH}_{3} \cdot \mathrm{C}^{\star}(\mathrm{WC})$ and $\mathrm{G}^{\star} \cdot \mathrm{C}^{*}{ }_{\mathrm{O} 2}(\mathrm{WC}) \leftrightarrow \mathrm{G}^{*} \mathrm{NH}_{3} \cdot \mathrm{C}\left(\mathrm{W}_{\mathrm{WC}}\right)_{\downarrow}$.

Gibbs free energies of activation for these reactions are $6.43,11.00$ and $1.63 \mathrm{kcal} \cdot \mathrm{mol}^{-1}$, respectively, obtained at the MP2/6-311 ++G(2df,pd)//B3LYP/6-311 + $+G(d, p)$ level of theory in gas phase under normal conditions $(T=298.15 \mathrm{~K})$.

In all cases without any exception tautomeric transitions are dipole active with minimum realized at the starting $\mathrm{G} \cdot \mathrm{C}^{\star \mathrm{t}}{ }_{\mathrm{O} 2}(\mathrm{WC})(9.98 \mathrm{D}), \mathrm{G} \cdot \mathrm{C}^{\star}{ }_{\mathrm{O} 2}(\mathrm{WC})(7.91 \mathrm{D})$ and $\mathrm{G} * \mathrm{C}^{*}{ }_{\mathrm{O} 2}(\mathrm{WC})(6.91 \mathrm{D})$ base pairs.

\section{Declarations}

Funding: Not applicable.

Conflicts of interest/Competing interests: Not applicable.

Availability of data and material: Not applicable.

Code availability: Gaussian'09 program package - gaussian.com; AIMAll program package http://aim.tkgristmill.com/.

Authors' contributions: OB - idea formulation, setting of the task, calculation of the data, building of the graphs, data extrapolation, preparing, and proofreading of the draft of the manuscript. AM - idea formulation, calculation of the data, building of the graphs, preparing, and proofreading of the draft of the 
manuscript. DH - idea formulation, preparing, and proofreading of the draft of the manuscript. All authors contributed to the article and approved the submitted version.

\section{References}

1. Brovarets' 00, Hovorun DM Renaissance of the tautomeric hypothesis of the spontaneous point mutations in DNA: New ideas and computational approaches. Mitochondrial DNA - New Insights / Ed. by Herve Seligmann, London, United Kingdom: IntechOpen (2018) ISBN 978-953-51-6167-7

2. Brovarets' OO, Hovorun DM (2014) Why the tautomerization of the G.C Watson-Crick base pair via the DPT does not cause point mutations during DNA replication? QM and QTAIM comprehensive analysis. J Biomol Struct Dynam 32:1474-1499

3. Florian J, Leszczynski J, Spontaneous (1996) DNA mutations induced by proton transfer in the guanine cytosine base pairs: An energetic perspective. J Am Chem Soc 118:3010-3017

4. Brovarets' 00, Hovorun DM (2010) How stable are mutagenic tautomers of the DNA bases? Biopol. Cell 26:72-76

5. Brovarets' 00, Hovorun DM (2020) A new era of the prototropic tautomerism of the quercetin molecule: A QM/QTAIM computational advances. J Biomol Struct Dynam 38:4774-4800

6. Brovarets' OO, Pérez-Sánchez HE, Hovorun DM (2016) Structural grounds for the 2-aminopurine mutagenicity: A novel insight into the old problem of the replication errors. RSC Adv 6:99546-99557

7. Pospisil P, Ballmer P, Scapozza L, Folkers G (2003) Tautomerism in computer-aided drug design. J Rec Sign Trans 23:361-371

8. Dhaked DK, Ihlenfeldt W-D, Patel H, Delannee V, Nicklaus MC (2020) Toward a comprehensive treatment of tautomerism in chemoinformatics including in InChI V2. J Chem Inf Model 60:12531275

9. Dobosz R, Kolehmainen E, Valkonen A, Ośmiałowski B, Gawinecki R (2007) Tautomeric preferences of phthalones and related compounds. Tetrahedron 63:9172-9178

10. Larina LI Tautomerism and structure of azoles. Adv. Het. Chem., 2018, 233-321

11. Brovarets' OO, Voiteshenko IS, Hovorun DM (2018) Physicochemical profiles of the wobble $\leftrightarrow$ WatsonCrick $G^{\star} \cdot 2 A P(w) \leftrightarrow G \cdot 2 A P(W C)$ and $A \cdot 2 A P(w) \leftrightarrow A^{*} \cdot 2 A P(W C)$ tautomerisations: $A$ QM/QTAIM comprehensive survey. Phys Chem Chem Phys 20:623-636

12. Gad SF, El-Demerdash SH, El-Mehasseb IM, El-Nahas AM (2019) Structure, stability and conversions of tautomers and rotamers of azulene-based uracil analogue. J Mol Struct 1182:271-282

13. Löwdin P-O (1963) Proton tunneling in DNA and its biological implications. Rev Mod Phys 35:724732

14. Löwdin P-O (1966) "Quantum genetics and the aperiodic solid: Some aspects on the biological problems of heredity, mutations, aging, and tumors in view of the quantum theory of the DNA molecule. In: " in Advances in Quantum Chemistry: Ed P.-O. Löwdin. Academic Press, New York, pp 213-360 
15. Polo DS, Mendieta-Moreno J, Trabada DG, Mendieta J, Ortega J. Proton transfer in guanine-cytosine base pairs in B-DNA. J. Chem. Theor. Comput., 2019, 156 6984-6991

16. Slocombe L, Al-Khalili JS, Sacchi M (2021) Quantum and classical effects in DNA point mutations: Watson-Crick tautomerism in AT and GC base pairs. Phys Chem Chem Phys 23:4141-4150

17. Ceron-Carrasco JP, Requena A, Zuniga J, Michaux C, Perpete EA, Jacquemin D (2009) Intermolecular proton transfer in microhydrated guanine-cytosine base pairs: A new mechanism for spontaneous mutation in DNA. J Phys Chem A 113:10549-10556

18. Brovarets' OO, Hovorun DM (2015) New structural hypostases of the A.T and G.C Watson-Crick DNA base pairs caused by their mutagenic tautomerisation in a wobble manner: A QM/QTAIM prediction. RSC Adv 5:99594-99605

19. Brovarets' OO, Oliynyk TA, Hovorun DM (2019) Novel tautomerisation mechanisms of the biologically important conformers of the reverse Löwdin, Hoogsteen, and reverse Hoogsteen $G * C *$ DNA base pairs via proton transfer: A quantum-mechanical survey. Front Chem 7:597

20. Brovarets' OO, Muradova A, Hovorun DM (2020) A quantum-mechanical looking behind the scene of the classical G.C nucleobase pairs tautomerization. Front Chem 8:574454

21. Brovarets' OO, Muradova A, Hovorun DM (2021) Novel mechanisms of the conformational transformations of the biologically important G.C nucleobase pairs in Watson-Crick, Hoogsteen and wobble configurations via the mutual rotations of the bases around the intermolecular $\mathrm{H}$-bonds: $\mathrm{A}$ QM/QTAIM study. RSC. Adv 11:25700-25730

22. Brovarets' OO, Hovorun DM (2015) Tautomeric transition between wobble A.C DNA base mispair and Watson-Crick-like A·C* mismatch: Microstructural mechanism and biological significance. Phys Chem Chem Phys 17:15103-15110

23. Brovarets' OO, Hovorun DM (2020) Quantum dancing of the wobble G.T(U/ $\left.{ }^{5 B r} U\right)$ nucleobase pairs and its biological roles. Chem Phys 1:100006

24. Brovarets' 00, Hovorun DM (2015) Novel physico-chemical mechanism of the mutagenic tautomerisation of the Watson-Crick-like A.G and C.T DNA base mispairs: A quantum-chemical picture. RSC Adv 5:66318-66333

25. Frisch, M.J., Trucks, G.W., Schlegel, H.B., Scuseria, G.E., Robb, M.A., \& Cheeseman,J.R., ... Pople, J.A. (2010). GAUSSIAN 09 (Revision B.01). Wallingford CT: Gaussian Inc

26. Parr RG, Yang W (1989) Density-functional theory of atoms and molecules. Oxford University Press, Oxford

27. Lee C, Yang W, Parr RG (1988) Development of the Colle-Salvetti correlation-energy formula into a functional of the electron density. Phys Rev B 37:785-789

28. Hariharan PC, Pople JA (1973) The influence of polarization functions on molecular orbital hydrogenation energies. Theor Chim Acta 28:213-222

29. Krishnan R, Binkley JS, Seeger R, Pople JA (1980) Self-consistent molecular orbital methods. XX. A basis set for correlated wave functions. J Chem Phys 72:650-654 
30. Matta CF (2010) How dependent are molecular and atomic properties on the electronic structure method? Comparison of Hartree-Fock, DFT, and MP2 on a biologically relevant set of molecules. $J$ Comput Chem 31:1297-1311

31. Brovarets' 00, Zhurakivsky RO, Hovorun DM (2015) DPT tautomerisation of the wobble guanine thymine DNA base mispair is not mutagenic: QM and QTAIM arguments. J Biomol Struct Dynam 33:674-689

32. Brovarets' OO, Hovorun DM (2021) Does the G.G* ${ }_{\text {syn }}$ DNA mismatch containing canonical and rare tautomers of the guanine tautomerise through the DPT? A QM/QTAIM microstructural study. Mol Phys 112:3033-3046

33. Peng C, Ayala PY, Schlegel HB, Frisch MJ (1996) Using redundant internal coordinates to optimize equilibrium geometries and transition states. J Comput Chem 17:49-56

34. García-Moreno BE, Dwyer JJ, Gittis AG, Lattman EE, Spencer DS, Stites WE (1997) Experimental measurement of the effective dielectric in the hydrophobic core of a protein. Biophys Chem 64:211224

35. Bayley ST (1951) The dielectric properties of various solid crystalline proteins, amino acids and peptides. Trans Faraday Soc 47:509-517

36. Frisch MJ, Head-Gordon M, Pople JA (1990) Semi-direct algorithms for the MP2 energy and gradient. Chem Phys Lett 166:281-289

37. Kendall RA, Dunning TH Jr, Harrison RJ (1992) Electron affinities of the first-row atoms revisited. Systematic basis sets and wave functions. J Chem Phys 96:6796-6806

38. Bader RF (1990) W. Atoms in molecules: A quantum theory. Oxford University Press, Oxford

39. Keith TA (2010) AIMAll (Version 10.07.01). Retrieved from aim.tkgristmill.com

40. Matta CF, Hernández-Trujillo J (2003) Bonding in polycyclic aromatic hydrocarbons in terms of the electron density and of electron delocalization. J Phys Chem A 107:7496-7504

41. Matta CF, Castillo N, Boyd RJ (2006) Atomic contributions to bond dissociation energies in aliphatic hydrocarbons. J Chem Phys 125:20, 204103

42. Cukrowski I, Matta CF (2010) Hydrogen-hydrogen bonding: A stabilizing interaction in strained chelating rings of metal complexes in aqueous phase. Chem Phys Lett 499:66-69

43. Lecomte C, Espinosa E, Matta CF (2015) On atom-atom 'short contact' bonding interactions in crystals. IUCrJ 2:161-163

\section{Figures}



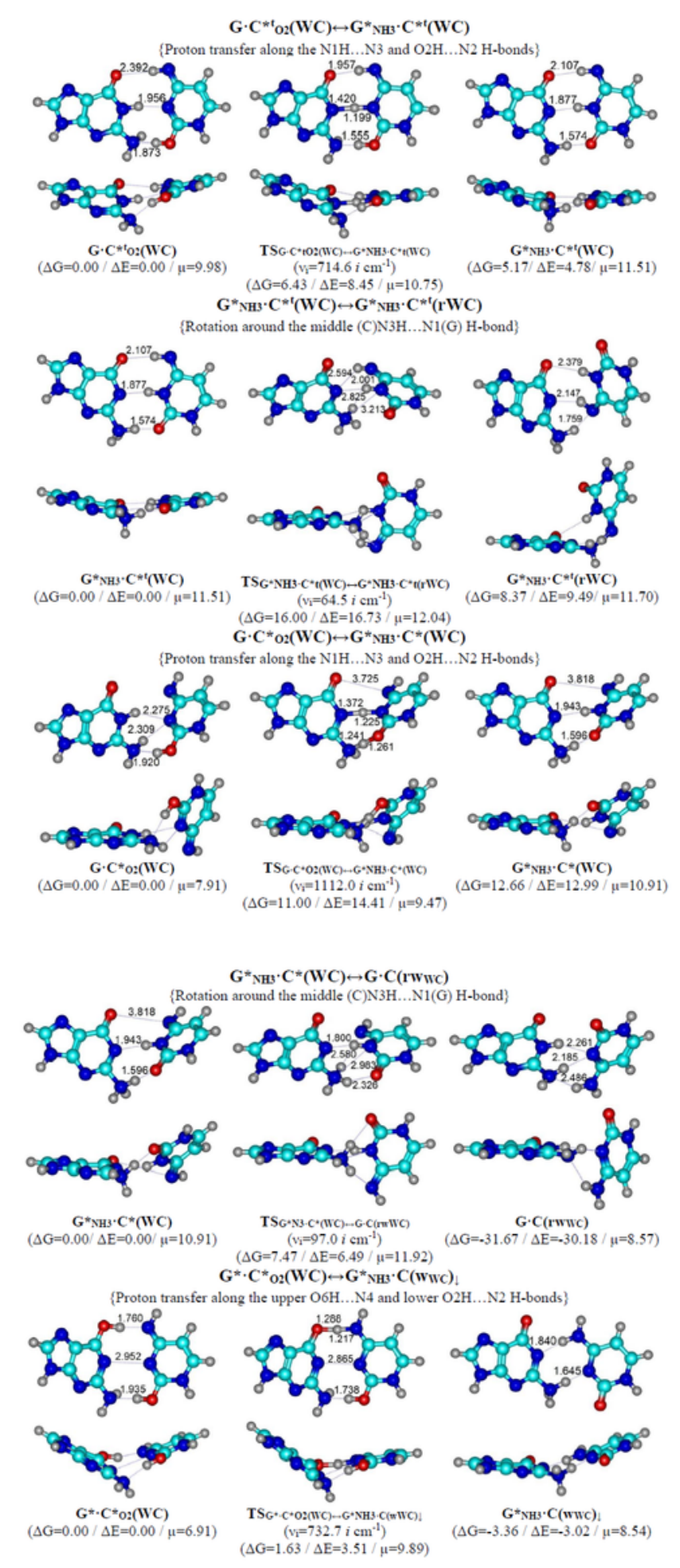

\section{Figure 1}

Tautomeric and conformational transformations of the $\mathrm{G} \cdot \mathrm{C}$ base pairs through the proton transfer and mutual rotations of the bases, obtained at the MP2/6-311++G(2df,pd)//B3LYP/6-311++G(d,p) level of theory in gas phase under normal conditions $(\Delta \mathrm{G}$ - relative Gibbs free energy $(T=298.15 \mathrm{~K}), \mathrm{kcal} \cdot \mathrm{mol}-1$; $\Delta \mathrm{E}$ - electronic energy, $\mathrm{kcal} \cdot \mathrm{mol}-1 ; \mathrm{vi}$ - imaginary frequency at the TS; $\mu$ - dipole moment of the complex, D). Intermolecular AH...B H-bonds and A...B van der Waals contacts are designated by the dotted 
lines, their lengths H...B and A...B are presented in Angstroms. Symbol " $\downarrow$ " means displacement of the base on the right down relatively the base on the left. 